\title{
Design Research: \\ Mengembangkan Kemampuan Berpikir Aljabar \\ Pada Pembelajaran Fungsi Dengan Pendekatan PMRI \\ Di SMP Negeri 7 Jakarta
}

\author{
Resti Eliyani, Pinta Deniyanti S., Puspita Sari \\ Program Studi Pendidikan Matematika, FMIPA UNJ
}

\begin{abstract}
Abstrak
Penelitian ini bertujuan untuk mengetahui bagaimana siswa dapat mengembangkan kemampuan berpikir aljabar pada pembelajaran fungsi dengan pendekatan matematika realistik.

Penelitian dilakukan mulai dari penyusunan proposal sampai dengan laporan hasil penelitian. Metodologi yang digunakan dalam penelitian ini adalah metode design research. Terdapat tiga fase penelitian yang digunakan pada penelitian design research, yaitu thought experiment (fase eksperimen hasil pemikiran), instruction experiment (fase eksperimen mengajar), dan analisis retrospektif. Subjek penelitian ini adalah enam siswa kelas VII-E di SMP Negeri 7 Jakarta. Data yang dikumpulkan berupa rekaman video dan foto selama pembelajaran berlangsung, hasil wawancara siswa, hasil kerja siswa, hasil diskusi, serta catatan lapangan di setiap pertemuan. Instrumen yang digunakan antara lain dokumentasi berupa rekaman video dan foto, lembar wawancara, lembar aktivitas siswa, lembar catatan lapangan, dan Hipotesis Lintasan Belajar (HLB). Ada dua jenis validasi pada penelitian ini yakni validasi internal dan validasi ekologi, sedangkan reliabilitas yang ada yakni reliabilitas internal dan reliabilitas eksternal.

Kemampuan berpikir aljabar siswa mengalami perkembangan melalui aktivitas yang telah dirancang sesuai dengan penguasaan keterampilan pada komponen berpikir aljabar Kriegler, yaitu 3 komponen berpikir matematis dan penguasaan 3 gagasan aljabar fundamental. Proses pembelajaran melalui rangkaian aktivitas berjalan sesuai dengan HLB yang sudah dirancang sebelumnya. Rangkaian aktivitas yang berkaitan dengan pendekatan Pendidikan Matematika Realistik Indonesia (PMRI) yang memperhatikan karakteristiknya pada penelitian design research ini dapat mengembangkan kemampuan berpikir aljabar siswa. Berdasarkan hasil analisis retrospektif, karakteristik PMRI berperan dalam mengembangkan kemampuan berpikir aljabar siswa pada pembelajaran fungsi di SMP Negeri 7 Jakarta.

Kata kunci: Kemampuan Berpikir Aljabar, Pendekatan Pendidikan Matematika Realistik Indonesia (PMRI), Pembelajaran Fungsi.
\end{abstract}

\section{PENDAHULUAN}

Pembelajaran matematika yang biasa dilakukan ialah siswa dilatih melakukan perhitungan matematika bukan dididik untuk berpikir secara matematis. Proses latihan menekankan pada makna belajar untuk mengetahui bagaimana melakukan suatu hal atau tuntutan terbatas hanya pada penyelesaian soal sehingga siswa hanya akan berpikir secara prosedural. Sedangkan didik menekankan pada 
mengapa hal tersebut ada atau bisa terjadi. Akibat dari pembelajaran matematika yang dilakukan hanya bergantung pada pengetahuan prosedural, banyak siswa Indonesia kurang memiliki kemampuan matematika. TIMSS (Trends in International Mathematics and Science Study) pada tahun 2003 menyurvei bahwa siswa Indonesia lemah dalam mengerjakan soal yang menuntut kemampuan penalaran bilangan pada sebuah pola. Hal tersebut dapat dikarenakan karena siswa belum dapat mengembangkan kemampuan berpikir aljabar secara optimal dan proses pembelajaran yang berlangsung kurang memfasilitasi siswa untuk mengembangkan kemampuan tersebut.

Prinsip-prinsip dan standar dari National Council of Teachers of Mathemaics (NCTM) memberikan lima standar isi matematika, yakni: bilangan dan operasinya, aljabar, geometri, pengukuran, serta analisis data dan probabilitas. Aljabar merupakan bagian dari matematika yang penting dan dapat digunakan untuk pemecahan masalah. Banyak siswa sekolah menengah pertama (SMP) yang beranggapan bahwa pembelajaran aljabar itu sulit dan abstrak. Padahal fokus pembelajaran aljabar di tingkat SMP ialah bagaimana mempersiapkan siswa untuk berpikir aljabar. Lemahnya kemampuan berpikir aljabar telah banyak mendapat penelitian yang menunjukkan bahwa anak-anak tidak mampu belajar aljabar karena tidak memiliki kemampuan kognitif untuk menangani konsep-konsep seperti variabel dan fungsi.

Berdasarkan observasi, wawancara, dan tes awal yang dilakukan di kelas VIII-E SMP Negeri 7 Jakarta, diperoleh hasil bahwa kemampuan berpikir aljabar siswa masih rendah. Hal tersebut ditandai dengan siswa yang belum memahami simbol-simbol alajabr, konsep variabel, menggeneralisasi pola, dan fungsi. Kebanyakan pembelajaran fungsi yang dilakukan bersifat formal dan siswa jarang diberikan soal-soal yang bersifat Problem Solving sehingga siswa hanya mampu mengembangkan kemampuan proseduralnya saja.

Salah satu pendekatan pembelajaran matematika yang menempatkan penerapan konsep matematika sebagai aspek penting dalam pembelajaran matematika dan menggunakan permasalahan yang ada dalam kehidupan seharihari atau realistis Adalah Pendidikan Matematika Realistik Indonesia (PMRI). Menurut Putri, Pendidikan Matematika Realistik memiliki lima karakteristik yaitu: menggunakan masalah kontekstual, menggunakan model, menghargai ragam jawaban dan kontribusi siswa, interaktivitas, dan terintegrasi dengan topik pembelajaran lainnya. Mengingat karakteri ini, PMRI dianggap sebagai pendekatan yang sangat menjanjikan untuk meningkatkan pembelajaran matematika dan membuatnya tidak hanya lebih relevan untuk siswa tetapi juga untuk mengubah iklim kelas.

Berdasarkan beberapa hal yang telah dipaparkan sebelumnya maka akan dikembangkan sebuah desain pembelajaran dalam penelitian ini dengan judul "Mengembangkan Kemampuan Berpikir Aljabar Pada Pembelajaran Fungsi Dengan Pendekatan PMRI Di SMP Negeri 7 Jakarta”.

\section{PENDIDIKAN MATEMATIKA REALISTIK INDONESIA}

Pendidikan matematika Realistik Indonesia (PMRI) merupakan pendekatan matematika realistik yang menggunakan landasan filosofi Realistic Mathematic 
Education (RME). RME berkembang di Belanda sejak awal tahun 1970-an oleh Freudenthal dan kawan-kawannya dari Fruedenthal Institute dengan gagasan "Mathematic is a human activity". Menurutnya, matematika harus dipandang sebagai suatu aktivitas manusia. Selain itu, agar matematika memiliki nilai kemanusiaan (human value) maka pembelajara harus berkaitan dengan realita, dekat dengan pengalaman siswa, dan terdapat hubungan dengan kehidupan seharihari. Freudenthal mengenalkan istilah "guided reinvention" sebagai proses yang dilakukan siswa secara aktif untuk menemukan kembali suatu konsep matematika dengan bimbingan guru. Treffers merumuskan lima karakteristik Pendidikan Matematika Realistik, yaitu: penggunaan konteks, penggunaan model untuk matematisasi progresif, pemanfaatan hasil konstruksi siswa, interaktivitas, dan keterkaitan. PMRI adalah pendekatan pembelajaran matematika yang menggunakan konteks dan bahan ajar terkait langsung dengan lingkungan sekolah dan siswa sehingga konteks dan bahan ajar tersebut dapat menjembatani siswa antara matematika informal dan matematika formal, siswa pun dapat berkontribusi dan aktif berpikir melalui interaktivitas yang terjadi didalam kelas serta proses pembelajaran pun memperhatikan keterkaitan antar konsep matematika.

\section{ALJABAR PADA TINGKAT SEKOLAH MENENGAH PERTAMA}

Usiskin mengungkapkan alasan pentingnya aljabar diajarkan di sekolah antara lain aljabar merupakan bahasa untuk mendeskripsikan suatu pola, aljabar memungkinkan seseorang untuk menjawab semua pertanyaan dari suatu jenis dalam satu waktu, aljabar merupakan bahasa yang menyatakan hubungan kuantitas atau jumlah, dan aljabar merupakan bahasa untuk menyelesaikan masalah-masalanumerik. Standar pembelajaran aljabar di SMP menurut NCTM: (1) Memahami pola, hubungan, dan fungsi; (2) Mewakili dan menganalisis situasi matematika dan struktur menggunakan simbol-simbol aljabar; (3) Menggunakan model matematika untuk mewakili dan memahami hubungan kuantitatif; dan (4) Menganalisis perubahan dalam berbagai konteks. Sesuai dengan Permen No 22 Tahun 2006, kompetensi dasar yang harus dimiliki siswa dalam pembelajaran fungsi antara lain memahami relasi dan fungsi, menentukan nilai fungsi, dan membuat sketsa grafik fungsi aljabar sederhana pada sistem koordinat Cartesius.

\section{PEMBELAJARAN FUNGSI}

Kata "hubungan" dapat digunakan untuk menghubungkan dua kelompok (himpunan). Hubungan antar anggota suatu himpunan yang satu dengan anggota himpunan lainnya dinamakan relasi. Diantara relasi-relasi, terdapat relasi yang bersifat khusus yang disebut fungsi. Fungsi adalah hubungan yang secara sederhana memasangkan himpunan-himpunan, dimana hubungan tersebut memiliki sifat tertentu, yakni untuk setiap $x$ ada tepat satu nilai $y$. Fungsi dapat diilustrasikan sebagai mesin fungsi yang terdiri dari input - process - output. Menurut Van de Walle, pola yang berkembang menunjukkan konsep dari fungsi dan fungsi dapat direpresentasikan dengan lima representasi yaitu konteks, bahasa, tabel, persamaan, dan grafik.

Fungsi memiliki beberapa macam, salah satunya korespondensi satu-satu dan fungsi konstan. Korespondensi satu-satu adalah fungsi yang memetakan anggota 
dari himpunan $\mathrm{A}$ dan $\mathrm{B}$, dimana semua anggota $\mathrm{A}$ dan $\mathrm{B}$ dapat dipasangkan sedemikian sehingga setiap anggota $A$ berpasangan dengan tepat satu anggota $B$ dan setiap anggota B berpasangan tepat satu anggota A. Jadi banyak anggota himpunan $\mathrm{A}$ dan $\mathrm{B}$ harus sama atau $n(\mathrm{~A})=n(\mathrm{~B})$. Fungsi Konstan jika dibuat grafik maka akan membentuk garis horizontal.

Grafik pada sistem koordinat cartesius merupakan salah satu representasi dari fungsi. Akan tetapi, terdapat pula grafik yang bukan merupakan fungsi. Terdapat tes yang dapat dilakukan untuk membedakan grafik fungsi dan bukan fungsi yaitu vertical line test. Vertical line test is if any vertikal line intersects a graph in more than one point, the graph does not define $y$ as function of $x$.

\section{ALGEBRAIC THINKING ATAU BERPIKIR ALJABAR}

Berpikir aljabar merupakan salah satu anggota pokok untuk berpikir dan analisis matematika. Kriegler dalam Hayati mengungkapkan bahwa kemampuan berpikir aljabar dapat dibagi ke dalam dua komponen utama, yaitu pengembangan alat berpikir matematis dan pembelajaran mengenai gagasan-gagasan aljabar fundamental seperti tabel 1 di bawah ini.

Tabel 1. Komponen-Komponen Berpikir Aljabar Kriegler

\begin{tabular}{|c|c|}
\hline \multicolumn{2}{|c|}{ Komponen-komponen berpikir aljabar } \\
\hline Alat berpikir matematis & Gagasan aljabar fundamental \\
\hline $\begin{array}{l}\text { Keterampilan pemecahan masalah: } \\
\text { Menggunakan strategi pemecahan masalah } \\
\text { dan menggunakan beberapa pendekatan. }\end{array}$ & $\begin{array}{l}\text { Aljabar sebagai generalisasi aritmetika: } \\
\text { Memahami konsep berdasarkan strategi } \\
\text { perhitungan; Rasio dan proporsi; dan Estimasi. }\end{array}$ \\
\hline $\begin{array}{l}\text { Keterampilan representasi: } \\
\text { Menampilkan hubungan-hubungan secara } \\
\text { visual, simbolis, numerik, dan verbal; } \\
\text { Menerjemahkan antara representasi- } \\
\text { representasi yang berbeda; dan Menafsirkan } \\
\text { informasi dalam representasi-representasi. }\end{array}$ & $\begin{array}{l}\text { Aljabar sebagai bahasa matematika: } \\
\text { Kebermaknaan variabel dan ekspresi variabel; } \\
\text { Kebermaknaan solusi; Memahami dan } \\
\text { menggunakan aturan sistem bilangan; } \\
\text { Membaca, menulis, memanipulasi bilangan, dan } \\
\text { simbol menggunakan konvensi aljabar; dan } \\
\text { Menggunakan representasi simbol ekuivalen } \\
\text { untuk memanipulasi formula, ekspresi, } \\
\text { persamaan, dan pertidaksamaan. }\end{array}$ \\
\hline $\begin{array}{l}\text { Keterampilan penalaran kuantitatif: } \\
\text { Menganalisis masalah untuk menggali dan } \\
\text { mengukur hal penting dan penalaran induktif } \\
\text { dan deduktif. }\end{array}$ & $\begin{array}{l}\text { Aljabar sebagai alat untuk fungsi dan } \\
\text { pemodelan matematika: } \\
\text { Mencari, membuat ekspresi, menggeneralisasi } \\
\text { pola, dan aturan dalam konteks kehidupan } \\
\text { nyata; Merepresentasi gagasan matematis } \\
\text { menggunakan persamaan, tabel, grafik, ataupun } \\
\text { kalimat; Bekerja dengan pola masuk/keluar.l; } \\
\text { dan Mengembangkan keterampilan membuat } \\
\text { grafik koordinat. }\end{array}$ \\
\hline
\end{tabular}

Kaput dalam Walle menjelaskan lima bentuk logika aljabar: generalisasi dari aritmetika dan pola yang ada di matematika; penggunaan simbol yang cukup bermanfaat; pembelajaran tentang struktur sistem bilangan; pembelajaran tentang pola dan fungsi; dan proses pemodelan matematis, yang menyatukan keempat ide tersebut. Kemampuan berpikir aljabar adalah kemampuan menggeneralisasi aritmetika dan pola, menggunakan simbol aljabar yang bermanfaat, memahami struktur sistem bilang dan fungsi, menggunakan model matematika untuk 
mewakili dan memahami hubungan kuantitatif, serta menganalisis, mengaplikasikan, dan memecahkan berbagai macam permasalahan, representasi, dan juga penalaran kuantitatif.

Pembelajaran fungsi dapat mencakup komponen-komponen utama kemampuan berpikir aljabar sehingga penelitian ini akan dilakukan pada pembahasan materi fungsi. Seperti yang telah diungkapkan oleh Walle bahwa pola dapat digunakan sebagai pengenalan dan menunjukkan konsep fungsi. Siswa dapat mengembangkan pola yang diberikan dan mengeneralisasi jumlah objek di setiap langkah pada pola tersebut. Terdapat dua cara untuk menemukan hubungan pada setiap pola yaitu hubungan rekursif dan hubungan fungsional.

\section{METODOLOGI PENELITIAN}

Penelitian ini menggunakan metode Design Research di kelas VII-E SMP Negeri 7 Jakarta semester 2 (genap) pada tahun ajaran 2015/2016. Tahap-tahap yang digunakan dalam design research meliputi: (1) Thought Experiment (Fase Persiapan dan Desain), (2) Teaching Experiment (Fase Pelaksanaan), (3) Retrospective Analysis (Fase Analisis Retrospektif). Pada fase persiapan dan desain, peneliti merancang aktivitas pembelajaran di kelas dan menyusun dugaan proses berpikir siswa. Pada fase pelaksanaan, dilakukan pembelajaran di kelas sesuai dengan aktivitas yang sudah disiapkan disertai dengan fase analisis retrospektif yakni menganalisis data yang sudah didapat sesuai dengan teori yang berlaku.

\section{HASIL PENELITIAN DAN PEMBAHASAN}

\section{Pertemuan Pertama: Memahami Relasi dan Fungsi serta Fungsi Korespondensi Satu-Satu dan Fungsi Konstan}

Pertemuan pertama terdiri dari dua aktivitas. Aktivitas 1 bertujuan agar siswa memahami relasi dan fungsi beserta representasinya, sedangkan aktivitas 2 bertujuan agar siswa memahami fungsi berkorespondensi satu-satu dan fungsi konstan. Alat yang digunakan selain Lembar Aktvitas Siswa (LAS) yaitu 1 lembar kertas HVS, dan 2 pack kertas berperekat berwarna hijau dan kuning. Aktvitas 1 dimulai dengan siswa dalam kelompoknya mengamati video tanaman hias dan mengamati hubungan antara tanaman hias dengan warna daun dan jenis akarnya.

Tabel 2 Tanaman Hias dengan Warna Daun dan Jenis Akarnya

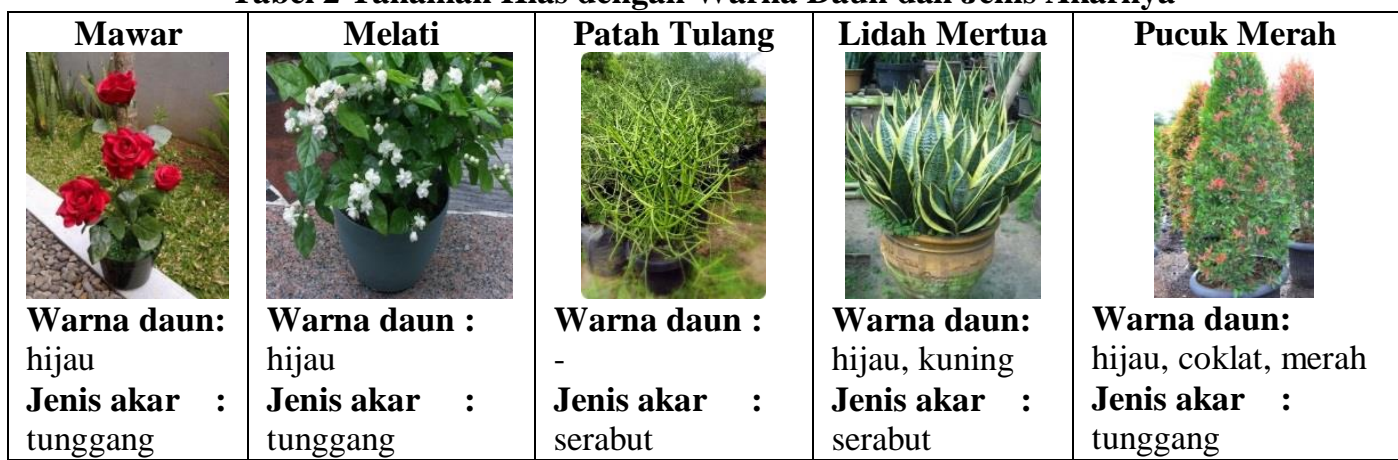

Catatan: Tanaman patah tulang tidak memiliki daun sehingga warna daunnya pun tidak ada (tidak memiliki warna daun) 
Sesuai dengan HLB, siswa memahami bahwa dalam penulisan pada kertas berperekat harus sesuai dengan daftar tanaman hias atau warna daun/jenis akar yang telah dikelompokan (daftar tanaman hias pada kertas berperekat berwarna sama dan warna daun/jenis akar juga di kertas berwarna sama) dan dalam penulisan warna daun/jenis akar sama memungkinkan siswa menuliskannya secara berulang namun setelah diberikan penjelasan siswa menuliskannya tidak lagi berulang. Penggunaan konteks tanaman hias dengan warna daunnya memperkenalkan siswa konsep relasi sedangkan tanaman hias dengan jenis akarnya memperkenal konsep fungsi. Selain itu, siswa pun dapat membuat representasi diagram panah dari konteks tersebut. Penggunaan konteks tanaman hias dan representasi diagram panah mempermudah siswa memahami relasi dan fungsi.

Aktivitas selanjutnya menggunakan konteks rute bus sekolah. Siswa diminta untuk mengamati warna lampu lalu lintas beserta artinya serta jumlah penumpang dan supir dalam sebuah bus. Hasil pengamatan siswa mengenai warna lampu lalu lintas beserta artinya bertujuan untuk membuat siswa memahami konsep fungsi berkorespondensi satu-satu sedangkan jumlah penumpang dan supir dalam sebuah bus untuk konsep fungsi konstan. Aktivitas 2 ini siswa dapat memahaminya dengan mudah karena serupa dengan aktivitas 1 . Siswa hanya sedikit mengalami kesulitan dalam memahami konteks jumlah penumpang dan supir dalam sebuah bus yang mana ketika hal te 1 naik 3 siswa dan 1 supir, lalu halte 2 naik 2 siswa jadi total 5 penumpang dan 1 supir, halte 3 naik 5 siswa jadi total 10 penumpang dan 1 supir, halte 4 naik 2 siswa jadi total 12 penumpang dan 1 supir, serta halte 5 naik 4 siswa jadi total 16 penumpang dan 1 supir. Sehingga diperoleh 3 terpasang ke 1, 5 terpasang ke 1, 10 terpasang ke 1, 12 terpasang ke 1, dan 16 terpasang ke 1. Hal tersebut menunjukkan konsep fungsi konstan.
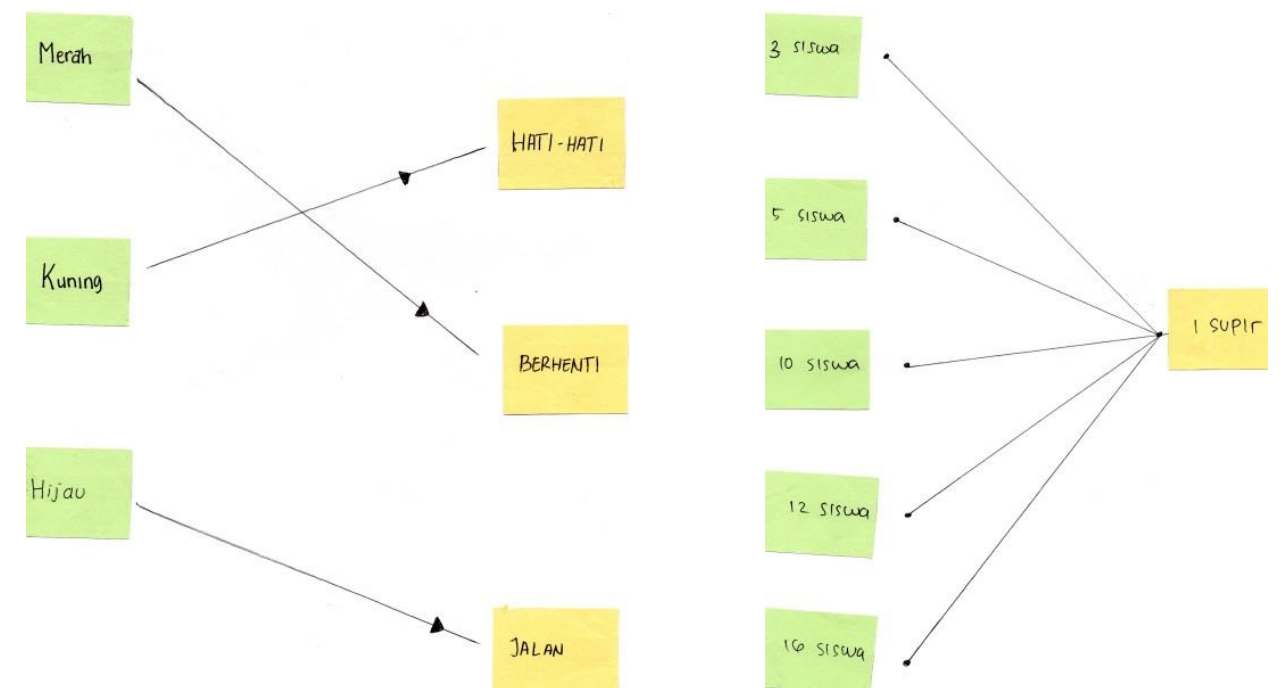

Gambar 1. Hasil Kerja Siswa Pada Aktivitas 2 Pertemuan Pertama

Aktivitas-aktivitas pada pertemuan pertama mengarahkan siswa untuk memahami konsep relasi dan fungsi, macam-macam fungsi, dan representasinya. Konteks yang diberikan pun mempermudah siswa untuk memahami konsep 
fungsi. Selain itu, representasi yang dihasilkan siswa pun beraneka ragam. Melaluui, diskusi baik dalam kelompok maupun kelas terjalin interaktivitas baik guru dengan siswa maupun antar siswa sendiri dan hal tersebut membuat siswa mengembangkan kemampuan representasi secara verbal.

\section{Pertemuan Kedua: Menentukan Nilai Fungsi dan Persamaan Fungsi Pada Sebuah Pola}

Kegiatan pertemuan kedua adalah menentukan nilai fungsi dan persamaannya. Aktivitas 1 yaitu menentukan banyaknya meja dan kursi pada konteks meja kantin sedangkan aktivitas 2 yaitu menentukan banyaknya kursi jika $x$ meja digabungkan. Konteks yang digunakan pada pertemuan kedua ini ada permasalahn pola meja kantin.

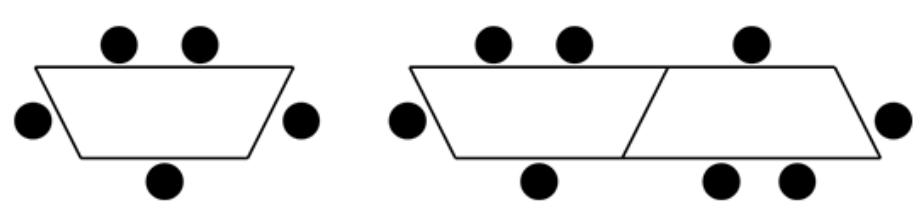

Gambar 2. Pola Permasalahan Meja Kantin

Aktivitas 1, siswa diberikan permasalahan dimana siswa harus mengembangkan pola hingga pola keempat. Sesuai dugaan pada HLB, siswa mengembangkan pola dengan cara meneruskan atau menggambar pola selanjutnya. Berdasarkan hasil diskusi kelas, terdapat siswa yang sudah memahami hubungan yang terjadi pada pola yang diberikan dan menggunakan konsep fungsi. Hasil konstruksi siswa tersebut pun membuat siswa lain menjadi paham mengenai hubungan yang terjadi dan memahami bahwa pola merupakan salah satu contoh fungsi.

Aktivitas selanjutnya siswa diberikan permasalahan yang mana siswa harus menggeneralisaikan pola. Berdasarkan hasil diskusi pada aktivitas sebelumnya, siswa tidak mengalami kesulitan dan siswa yang awalnya menggunakan gambar pun memahami bahwa dengan menentukan hubungan yang terjadi lebih memudahkan menyelesaikan permasalahan yang diberikan. Akan tetapi, siswa mengalami kesulitan dalam membuat persamaan fungsi. Hal tersebut, dikarenakan tingkat kesukaran yang lebih dibandingkan sebelumnya yaitu siswa diminta membuat representasi persamaan dari pola yang diberikan. Namun, dengan bimbingan guru pun siswa dapat menentukan representasi persamaan yang dimaksud. Guru pun memberikan penekanan mengenai persamaan fungsi yang telah siswa peroleh dan memberikan penjelasan mengenai nilai fungsi, variabel, koefisien, dan juga konstanta. Berdasarkan hasil diskusi antara peneliti, guru, dan observer, pertemuan kedua dapat berjalan dengan baim. Siswa dapat memahami dengan baik nilai fungsi dan persamaan fungsi.

\section{Pertemuan Ketiga: Membuat Grafik Fungsi serta Membedakan Grafik Fungsi Dengan Grafik Bukan Fungsi Dengan Vertical Line Test}

Aktivitas 1 pada pertemuan ketiga masih menggunakan konteks yang sama seperti pertemuan kedua yaitu pola meja kantin, namun pada aktivitas ini siswa akan mempelajari representasi grafik. Masing-masing kelompok diberikan alat peraga yaitu 1 gabus berpetak, pin, dan benang. Sedangkan pada aktivitas 2 untuk 
membedakan grafik fungsi dan bukan fungsi, masing-masing kelompok akan diberikan penggaris serta penggunaan software GeoGebra oleh guru.

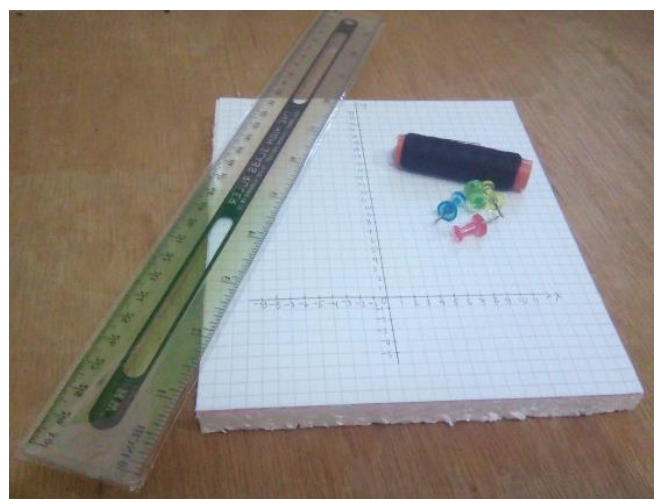

(a)

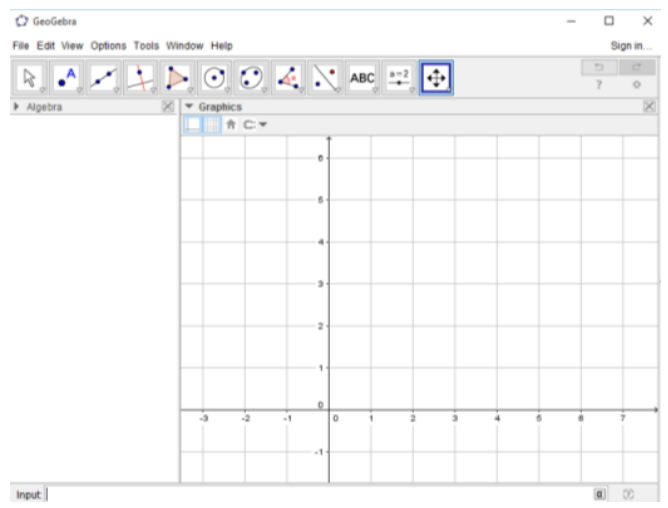

(b)

Gambar 3. (a) Alat Peraga Pertemuan 3, (b) GeoGebra

Sesuai dengan dugaan bahwa setelah semua kelompok diberikan LAS dan alat peraga, siswa terlihat heran dan bingung mengenai alat-alat yang diberikan sehingga guru pun memberikan penjelasan bahwa alat-alat yang digunakan untuk membuat grafik yaitu gabus berpetak sebagai koordinat Cartesius, pin sebagai titik, dan benang sebagai penghubung antar titik. Setelah diberikan penjelasan, siswa pun paham dan mampu membuat representasi grafik. Grafik yang dihasilkan siswa sesuai dugaan pada HLB yaitu grafik yang dibuat terbatas pada titik yang diketahui saja. Selain itu, pada pertanyaan mengenai penyebab kelinearan grafik fungsi linear siswa dituntut untuk mengembangkan kemampuan penalarannya. Terdapat siswa yang mampu mengungkapkan penyebab kelinearan tersebut dengan tepat, tetapi ada juga siswa yang berpendapat bahwa garis yang terbentuk pada grafik linear bukanlah garis lurus melainkan garis miring. Hal itu dikarenakan siswa melihat posisi grafik $y=3 x+2$ yang miring. Oleh karena itu, dibutuhkan peranan guru untuk mengatur jalannya diskusi dan memahami konsep-konsep matematika.

Aktivtas dilanjutkan pada aktivitas 2 yang dimulai dengan guru menampilkan software GeoGebra dan membuat beberapa grafik yang terdapat pada LAS aktivitas 2 dengan menggunakan GeoGebra. Siswa pun terlihat antusias karena siswa jadi tahu bahwa terdapat sofware matematika yang dapat siswa gunakan salah satunya untuk membuat grafik dan juga siswa memahami bahwa mebuat grafik dapat diperpanjang tidak terbatas pada titik yang diketahui saja.

Siswa berkelompok seperti aktivitas 1 dan diminta untuk membaca instruksi pada LAS mengenai vertical line test. Sesuai dugaan, siswa kurang paham akan maksud titik potong tersebut. Akhirnya guru pun memberikan penjelasan mengenai cara melakukan vertical line test yaitu dengan menggeser penggaris tegak lurus dengan sumbu $X$ pada setiap absis lalu menentukan titik potong antara grafik dengan menggaris tersebut terdapat 1 titik potong, lebih dari 1, atatu tidak ada. Berdasarkan penjelasan guru, siswa menjadi paham instruksi yang dimaksud dan siswa pun berdiskusi dengan kelompoknya masing-masing untuk menyelesaikan pertanyaan-pertanyaan yang terdapat pada LAS. 


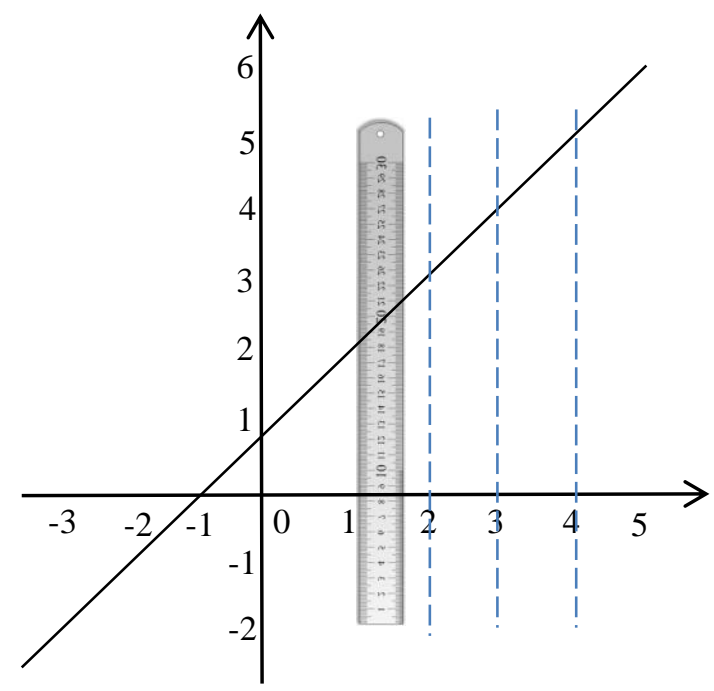

Gambar 4. Ilustrasi Vertical Line Test Grafik $y=x+1$

Berdasarkan proses diskusi kelas dan hasil pengamatan guru selama proses diskusi kelompok, sebagian besar siswa sudah paham membedakan grafik fungsi dan bukan fungsi dengan menggunakan vertical line test. Ditemukan bahwa sebagian besar siswa terkecoh grafik fungsi kuadrat merupakan grafik bukan fungsi, hal tersebut dikarenakan siswa hanya mempelajari grafik fungsi linear. Oleh karena itu, guru pun memberikan penjelasan dengan mengaitannya dengan definisi fungsi. Akhirnya, siswa pun paham bahwa grafik fungsi kuadrat tersebut termasuk grafik fungsi. Hal itu pun menjadi pengetahuan tambahan bagi siswa bahwa fungsi itu tidak hanya fungsi linear saja melainkan fungsi kuadrat pun merupakan fungsi.

Berdasarkan hasil analisis retrosperktif dapat disimpulkan beberapa kelebihan dalam penelitian ini yakni siswa dapat memahami konsep relasi dan fungsi beserta representasinya dengan baik, siswa dapat lebih aktif karena pembelajaran didominasi dengan diskusi, serta siswa dapat membayangkan dengan baik setiap bahasan dalam pembelajaran ini. Sedangkan kekurangan dalam desain penelitian ini yakni guru harus memiliki kemampuan yang baik dalam mengontrol keefektifan waktu pelaksanaan masing-masing aktivitas karena terdapat aktivitas yang membutuhkan waktu cukup lama dan juga pemahaman yang baik mengenai fungsi termasuk grafik fungsi.

\section{KESIMPULAN}

Dari penelitian ini dapat disimpulkan bahwa karakteristik PMRI berperan dalam mengembangkan kemampuan berpikir aljabar siswa kelas VII-E SMP Negeri 7 Jakarta dalam memahami konsep relasi dan fungsi. Proses pembelajaran melalui aktivitas yang sudah dirancang berjalan sesuai dengan HLB yang sudah dirancang sebelumnya. Rangkaian kegiatan yang berhubungan dengan kemampuan berpikir aljabar pada penelitian design research dengan menggunakan pendekatan PMRI dan memperhatikan karakteristiknya mampu mengembangkan kemampuan berpikir aljabar siswa. Kemampuan ini mampu 
membangun kemampuan generalisasi dan pemahaman siswa mengenai konsep fungsi.

\section{DAFTAR PUSTAKA}

Badan Standar Nasional Pendidikan (BNSP). "Lampiran Peraturan Menteri Menteri Pendidikan Nasional Republik Indonesia No 22 Tahun 2006 tentang Standar isi." Online. http://www.bsnp-indonesia.org/. Diakses_6 Mei 2015.

Hayati, Laila. (2013). "Pembelajaran Pendidikan Matematika Realistik Untuk Mengembangkan Kemampuan Berpikir Aljabar Siswa." Online. http://eprints.uny.ac.id/10773/1/P\%20-\%2050.pdf. Diakses 29 Maret 2015.

Jhonson Art., Leonard M. Kennedy, dan Steve Tipps. (2008) Guiding Children's Learning of Mathematics 12th Edition. USA: Wadsworth.

Putri, Ratu Ilma Indra. (2011). "Improving Mathematics Comunication Ability of Student in Grade 2 Through PMRI Approach." Online. http://eprints.uny.ac.ic/1371. Diakses 1 Oktober 2015.

Sonnabend, Thomas. (2010). Mathematics for Teacher: An Interactive Approach for Grades K-8 Fourth Edition. Canada: Brooks/Cole,Cengage Learning.

Suryadi, Didi. (2007). Pendidikan Matematika dalam Ilmu dan Aplikasi Pendidikan. Bandung: Pedagogiana Press.

Usiskin, Zalman. (1999). Why is Algebra Important to Learn dalam B. Moses (Eds.)Algebraic Thingking: Reading From NCTM's School Based Journal and other Publication. Reston: National Council of Teacher of Mathematics.

Walle, John A. Van de. (2007). Matematika Sekolah Dasar dan Menengah Edisi Keenam. Jakarta: Penerbit Erlangga.

Wardhani, Sri dan Rumiati. "Instrumen Penilaian Hasil Belajar Matematika SMP: Belajar dari PISA dan TIMSS." Online. http://p4tkmatematika.org. Diakses 12 November 2015.

Wijaya, Ariyadi. (2012). Pendidikan Matematika Realistik Suatu Alternatif Pendekatan Pembelajaran Matematika. Yogyakarta: Graha Ilmu.

Yee, Lee Peng. (2006). Teaching Secondary School Mathematics. Singapore: Mc Graw Hill. 